Article

\title{
Pan-Proteomic Analysis and Elucidation of Protein Abundance among the Closely Related Brucella Species, Brucella abortus and Brucella melitensis
}

\author{
Jayaseelan Murugaiyan ${ }^{1,2, *(\mathbb{D}) \text {, Murat Eravci }}{ }^{3,4}$, Christoph Weise ${ }^{3}{ }^{(0)}$, Uwe Roesler ${ }^{1}$, \\ Lisa D. Sprague ${ }^{5}$, Heinrich Neubauer ${ }^{5}$ and Gamal Wareth ${ }^{5,6}$ (D) \\ 1 Institute of Animal Hygiene and Environmental Health, Freie Universität Berlin, Centre for Infectious \\ Medicine, Robert-von-Ostertag-Str. 7-13, 14163 Berlin, Germany; uwe.roesler@fu-berlin.de \\ 2 Department of Biotechnology, SRM University AP, Andhra Pradesh, Neerukonda, Mangalagiri, \\ Guntur 522 502, India \\ 3 Institute of Chemistry and Biochemistry, Freie Universität Berlin, Thielallee 63, 14195 Berlin, Germany; \\ murat.eravci@gmx.de (M.E.); chris.weise@biochemie.fu-berlin.de (C.W.) \\ 4 Sussex Neuroscience, School of Life Sciences, University of Sussex, Falmer, Brighton BN1 9QG, UK \\ 5 Friedrich-Loeffler-Institute, Institute of Bacterial Infections and Zoonoses, Naumburger Str. 96a, 07743 Jena, \\ Germany; lisa.sprague@fli.de (L.D.S.); heinrich.neubauer@fli.de (H.N.); gamal.wareth@fli.de (G.W.) \\ 6 Faculty of Veterinary Medicine, Benha University, Moshtohor, Toukh 13736, Egypt \\ * Correspondence: Jayaseelan.m@srmap.edu.in; Tel.: +91-6383557214
}

Received: 10 March 2020; Accepted: 19 May 2020; Published: 30 May 2020

\begin{abstract}
Brucellosis is a zoonotic infection caused by bacteria of the genus Brucella. The species, B. abortus and B. melitensis, major causative agents of human brucellosis, share remarkably similar genomes, but they differ in their natural hosts, phenotype, antigenic, immunogenic, proteomic and metabolomic properties. In the present study, label-free quantitative proteomic analysis was applied to investigate protein expression level differences. Type strains and field strains were each cultured six times, cells were harvested at a midlogarithmic growth phase and proteins were extracted. Following trypsin digestion, the peptides were desalted, separated by reverse-phase nanoLC, ionized using electrospray ionization and transferred into an linear trap quadrapole (LTQ) Orbitrap Velos mass spectrometer to record full scan MS spectra $(\mathrm{m} / \mathrm{z} 300-1700)$ and tandem mass spectrometry (MS/MS) spectra of the 20 most intense ions. Database matching with the reference proteomes resulted in the identification of 826 proteins. The Cluster of Gene Ontologies of the identified proteins revealed differences in bimolecular transport and protein synthesis mechanisms between these two strains. Among several other proteins, antifreeze proteins, Omp10, superoxide dismutase and $30 \mathrm{~S}$ ribosomal protein S14 were predicted as potential virulence factors among the proteins differentially expressed. All mass spectrometry data are available via ProteomeXchange with identifier PXD006348.
\end{abstract}

Keywords: pan-proteomics; Brucella abortus; Brucella melitensis; label-free quantitative analysis; LC-ESI-MS/MS

\section{Introduction}

Brucella represents a Gram-negative bacterial genus of the $\alpha-2$ subgroup of Proteobacteria. Brucellae are highly adapted to their intracellular lifestyle and are the causative agents of human and animal brucellosis ("undulant fever", "Malta fever", "Mediterranean fever" or "Bang's disease") [1]. They are highly infective and 10-100 bacteria cause human infection [2,3]. The genus Brucella currently includes 12 accepted species that have been named according to their host specificity. To date, the mechanism behind the host specificity is not clear [4]. The classification of Brucella species is under debate due 
to the reported high degree of homology found in DNA-DNA hybridization studies. This results in the proposal that the genus Brucella is a single genomospecies and the species are only biovars of B. melitensis $[5,6]$. It is also believed that $B$. abortus and B. melitensis share a common ancestor that evolved from B. suis [7]. B. abortus (preferred host: cattle and other bovidae), B. melitensis (small ruminants such as goats and sheep) and B. suis (pigs) cause human brucellosis. The Centers for Disease Control and Prevention has listed Brucella species on the Federal Select Agent Program/Select Agents and Toxins List (https://www.selectagents.gov/SelectAgentsandToxinsList.html, assessed in March 2020) and on the Emergency Preparedness and Response Bioterrorism Agents/Diseases List (https://emergency.cdc.gov/agent/agentlist.asp, assessed in March 2020) as prepared by the National Center for Emerging and Zoonotic Infectious Diseases.

B. melitensis and B. abortus have striking similarities, i.e., two chromosomes, comparable gene sequence, organization and structure [7-9]. These two species are the most often sequenced species of Brucella with 256 genome assemblies of $B$. abortus and 254 genome assemblies of B. melitensis listed at the NCBI database (March 2020) [8,9]. The genome size of the B. abortus type strain 544 was reported to be $3,289,405 \mathrm{bp}$ and was predicted to possess 3319 genes among which 3259 were protein-coding genes and 60 RNA genes [10]. The genome of B. melitensis strain $16 \mathrm{M}$ encompasses 3,294,935 bp distributed over two circular chromosomes and contains 3197 open reading frames (ORFs), potentially available for expression [11]. Comparison of the B. melitensis $16 \mathrm{M}$ genome with strains of five other Brucella species revealed alterations in ORFs and species-specific conservation in terms of genetic content deletion or missing genome islands [12]. The host specificity might be caused by the species-specific gene inactivation/activation that influences transcriptional regulators and outer membrane proteins $[7,13,14]$. Previous studies indicated that these two strains vary in their antigenicity, immunologic and genetic properties [15-17]. There is no clear information in the literature designating whether live attenuated B. abortus and B. melitens is strains provide cross-protection among bovines and small ruminants respectively $[18,19]$. These two species display differences in phenotype, e.g., dye sensitivity, $\mathrm{CO}_{2}$ requirement or $\mathrm{H}_{2} \mathrm{~S}$ production, which are used for diagnosis and biotyping [4,20-22]. Differences in immuno-dominant proteins of field isolates were demonstrated using sera collected from naturally infected animals $[23,24]$. Although it is broadly accepted in the field that the Type IV secretion system (T4SS) is in some way tied to virulence in Brucella species, Brucella generally lacks classical virulence factors and in order to explain its virulence and host specificity, a better understanding at the proteome and metabolome level is needed. Proteomic analyses of various strains of $B$. abortus and $B$. melitensis have been reported [25-34], suffering from limitations in terms of technology and database coverage. In the present study, the label-free quantitative proteomic analysis includes the reference strains as well as strains isolated from infected animals analyzed in an earlier study [23]. The focus of this study was to investigate proteome level differences between B. abortus and B. melitensis cultured under laboratory conditions and relate them to possible factors involved in mechanisms of virulence and differences in host specificity.

\section{Materials and Methods}

\subsection{Brucella Culture}

Brucella type strains and field isolates as listed in Table 1 were from the culture collection of the Friedrich-Loeffler-Institut (FLI), Federal Research Institute for Animal Health, Institute of Bacterial Infections and Zoonoses (IBIZ), Jena, Germany. Each strain was independently cultivated 6 times in $50 \mathrm{~mL}$ of Tryptic Soy Broth at $37^{\circ} \mathrm{C}$ in the presence of $5 \% \mathrm{CO}_{2}$ with shaking until the CFU was around $5 \times 10^{8}$ cells $/ \mathrm{mL}$. The cells were harvested by centrifugation at $11290 \times g$ for $5 \mathrm{~min}$ and after washing twice with phosphate buffer saline, the cells were inactivated and fixed by reconstituting the cell pellets with $300 \mu \mathrm{L}$ of high performance liquid chromatography (HPLC) grade distilled water and $900 \mu \mathrm{L}$ of absolute ethanol. 
Table 1. Brucella strains used in this study.

\begin{tabular}{|c|c|c|c|c|c|}
\hline \multirow{2}{*}{ Strain } & \multicolumn{3}{|c|}{ Designation/ID/Number } & \multirow{2}{*}{ Host } & \multirow{2}{*}{ Geographical Region } \\
\hline & FAO & ATCC & NCTC & & \\
\hline B. melitensis $\mathrm{T}$ & $16 \mathrm{M}$ & 23456 & 10094 & Goat & USA \\
\hline B. abortus $\mathrm{T}$ & 544 & 23448 & 10093 & Cattle & UK \\
\hline B. melitensis & $C^{*}$ & & & Sheep & China \\
\hline B. abortus & $\mathrm{T}^{*}$ & & & Cattle & Turkey \\
\hline
\end{tabular}

T Type strain, FAO-Food and Agriculture Organization * ID assigned to the field strains deposited at the culture collections of Friedrich-Loeffler-Institut, Jena, Germany (C: China, T: Turkey), ATCC-American Type Culture Collection, NCTC - National Collection of Type Cultures, UK.

\subsection{Whole-Cell Protein Extraction}

In order to extract proteins from the ethanol-fixed cells, cells were centrifuged at $11,290 \times g$ for $2 \mathrm{~min}$, the supernatant was discarded and the resultant cell pellets were air-dried for $20 \mathrm{~min}$ to remove ethanol traces. The cell precipitate was then reconstituted in $250 \mu \mathrm{L}$ of lysis buffer $(20 \mathrm{mM}$ HEPES, pH 7.4), sonicated on ice for 1 min (duty cycle: 1.0, amplitude: 100\%, UP100H; Hielscher Ultrasound Technology, Teltow, Germany), centrifuged at $11,290 \times g$ for 5 min at $4{ }^{\circ} \mathrm{C}$ and the supernatant collected. The protein content was measured using a modified Bradford's method (Biorad, Munich, Germany). The values obtained were checked for consistency by Sodium Dodecyl Sulfate PolyAcrylamide Gel Electrophoresis (SDS-PAGE) [35]. A volume of the whole-cell extract containing $10 \mu \mathrm{g}$ of protein was subjected to acetone precipitation, reconstituted in $10 \mu \mathrm{L}$ sample loading buffer, heated for $5 \mathrm{~min}$ at $60{ }^{\circ} \mathrm{C}$ and subjected to gel electrophoresis ( $4 \%$ acrylamide concentration in the stacking and $12 \%$ acrylamide concentration in the separating gel); the protein bands were visualized using Coomassie staining [36].

\subsection{In Solution Trypsin Digestion}

The protein extract containing $10 \mu \mathrm{g}$ of protein was subjected to acetone precipitation and trypsin digestion as described elsewhere [37]. In brief, following acetone precipitation, the precipitate was reconstituted with $10 \mu \mathrm{L}$ of denaturation buffer (6 M urea/2 M thiourea in $10 \mathrm{mM}$ HEPES, pH 8.0). All steps of in-solution trypsin digestion were carried out at room temperature. The reduction was carried out for $30 \mathrm{~min}$ by adding $0.2 \mu \mathrm{L}$ of $10 \mathrm{mM}$ dithiothreitol in $50 \mathrm{mM}$ of ammonium bicarbonate (ABC). Subsequently, alkylation was performed for $30 \mathrm{~min}$ by adding $0.2 \mu \mathrm{L}$ of $55 \mathrm{mM}$ iodoacetamide in $50 \mathrm{mM}$ ABC. Then, $0.4 \mu \mathrm{L}$ of LysC $(0.5 \mu \mathrm{g} / \mu \mathrm{L}$; Wako, Neuss, Germany) in ABC solution was added and incubated overnight at room temperature. Next, $75 \mu \mathrm{L}$ of $\mathrm{ABC}$ were added to decrease the urea concentration to $<2 \mathrm{M}$ to enable trypsin digestion. Trypsin digestion was carried out overnight at $37^{\circ} \mathrm{C}$ after adding $0.4 \mu \mathrm{L}$ of $0.5 \mu \mathrm{g} / \mu \mathrm{L}$ trypsin in $50 \mathrm{mM} \mathrm{ABC}$ and the reaction was arrested by adding $100 \mu \mathrm{L}$ of $5 \%$ acetonitrile in $3 \%$ trifluoroacetic acid.

\subsection{Liquid Chromatography-Electrospray Ionization-Tandem Mass Spectrometry (LC-ESI-MS/MS)}

The trypsin-digested peptides were first desalted by solid-phase extraction, using the stage-tip procedure [38]. Nano liquid chromatography-tandem mass spectrometry (LC-MS/MS) analysis was carried out using a Dionex Ultimate 3000 nanoLC system (Dionex, Germering, Germany) coupled with an LTQ Orbitrap Velos mass spectrometer (Thermo Fisher Scientific, Bremen, Germany), operated in data-dependent acquisition mode with the Xcalibur software (version 21.0.1140, Thermo Fisher Scientific). The nanoLC system was used to load the peptides in $0.1 \%$ formic acid onto a C18 PepMap trap column $(75 \mu \mathrm{m}$ ID $\times 2 \mathrm{~cm}$, Dionex). Then, separation was achieved with a 5-60\% acetonitrile gradient $(90 \mathrm{~min}$ ) with $0.1 \%$ formic acid at a flow rate of $350 \mathrm{~nL} / \mathrm{min}$ through a $25 \mathrm{~cm}$ fritless C18 microcolumn packed inhouse with ReproSil-Pur C18-AQ $3 \mu \mathrm{m}$ resin (Dr. Maisch GmbH, Entringen, Germany). Online electrospray ionization with an electrospray voltage of $2 \mathrm{kV}$ was used for direct ionization of the eluted peptides. The ions were then transferred into an LTQ Orbitrap Velos operated 
in the positive mode to record full scan MS spectra (from $m / z$ 300-1700) at a resolution of $\mathrm{R}=60,000$ followed by isolation and fragmentation of the 20 most intense ions by collision-induced dissociation.

\subsection{Protein Identification}

All raw MS files were combined and processed with the MaxQuant software (version. 1.6.0.16/Max-Planck-Institute of Biochemistry, Martinsried, Germany) [39,40]. The following parameters were set for protein identification: minimum required peptide length, seven amino acids, enzymes, LysC and trypsin, both enzymes with two missed cleavages, fixed modification, cysteine carbamidomethylation and variable modifications, oxidation of methionine and protein $\mathrm{N}$-terminal acetylation. The initial precursor and fragment ion maximum mass deviations were set to $7 \mathrm{ppm}$ and $0.5 \mathrm{Da}$, respectively, for the search against forward and backward protein sequences of a combined Brucella database (B. abortus 2308 and B. melitensis M28) downloaded from the UniProt Knowledgebase. The target-decoy-based false discovery rate (FDR) for peptide and protein identification was set to 0.01 to ensure that the proteins identified with the lowest score had a probability of $\leq 1 \%$ of being a false identification. The most frequently observed laboratory contaminants were eliminated from the list of identified proteins and the proteins with at least one peptide unique to the protein sequence were considered as valid identifications. MS-based quantification of proteins was performed using the label-free quantification algorithm of the MaxQuant software package [41,42].

\subsection{Data Analysis}

The data analysis was carried out using the freely available software Perseus (version 1.4.1.3; Max-Planck-Institute of Biochemistry, Martinsried, Germany), after importing the label-free quantification (LFQ) intensities of the proteins from the MaxQuant analysis. The intensities were first transformed to a logarithmic scale with base two and the missing values were replaced (imputated) with the value of the lowest observed value in the dataset. Statistical analysis was carried out using a two-way Student $t$-test, error correction $(p<0.05)$ and FDR correction of the alpha error was carried out by the method of Benjamini-Hochberg [43]. The comparisons between the four different datasets (type and reference strains of each species) were carried out in different pairs. Heat map and hierarchical clustering of proteins (Euclidean distance and linkage) were calculated using $z$-score normalized and logarithmized intensities of identified proteins. For further visualization, volcano plots and principle component analysis (PCA) were performed. All the proteins that showed a fold-change of at least 1.5 and met $p>0.05$ were considered differentially expressed.

The mass spectrometry data have been deposited to the ProteomeXchange Consortium via the PRIDE partner repository [44,45], with the dataset identifier PXD006348.

\subsection{Functional Categorization and Pathways Analysis}

The UniProt FASTA files of protein sequences were analyzed using http://eggnogdb.embl.de (assessed in February 2017) to achieve the functional annotation of the identified proteins in terms of clusters of orthologous group (COG) [46]. The canonical pathways were also analyzed using the Database for Annotation, Visualization and Integrated Discovery (DAVID) tool [47,48].

\subsection{Screening for Virulence-Associated Proteins}

Protein sequences downloaded from Uniprot in FASTA format were used to predict the virulence nature using the VirulentPred online analysis tool (http://bioinfo.icgeb.res.in/virulent/ assessed in Sep. 2019) [49].

\subsection{Mass Spectrometry Data}

The mass spectrometry proteomics data have been deposited to the ProteomeXchange Consortium [50] via the PRIDE partner repository with the dataset identifier PXD006348. 


\section{Results and Discussion}

In the present study, the reference strains B. abortus (strain 544, ATCC 23448) and B. melitensis (strain 16M, ATCC 23456) [10,11,26] were chosen in an attempt to understand the proteomic differences between strains of closely related Brucella species. The strains isolated from infected animals that were previously used to demonstrate the existence of protein expression level differences [23] were also included for comprehension. Differences at the proteome level may also underlie differences in their phenotypes, pathogenicity and host specificity [22,51,52]. The vaccine strain Rev. 1 and the laboratory strain B115 of B. melitensis had comparable two-dimensional gel electrophoresis (2DE) protein patterns. However, the reference strain 16M displayed 50\% fewer protein spots [53]. Strains of the same species possessing homologous genomes and displaying comparable phenotype or biochemical reactions [54] also displayed different proteomes in B. abortus strains, i.e., the virulent strain 2308 and the vaccine strain S19 [55]. Earlier genome-based suppressive subtractive hybridization studies had identified species-specific deletions which 2DE-based investigations could not confirm $[27,28,56]$ due to the limitations in available protein identification coverage and of protein entries in the database. Factors such as heat, oxidative and acidic $\mathrm{pH}$ stress and culture media have influenced the 2DE based protein coverage of B. abortus and B. melitensis [32,57]. Application of LC-MS has enhanced the protein coverage as demonstrated in the case of reference strain B. abortus 2308 to create a dataset of 621 proteins among which 300 were not reported earlier and five were attributed to pseudogenes [29]. LC-MS-based quantitative proteomic comparison of the outer membrane fraction of virulent and avirulent strains of $B$. abortus results in the fact that Brucella virulence is based on extensive cell envelope-based modifications $[26,30,55]$. Therefore, the present study involving LC-MS-based quantitative proteomic analysis of whole-cell protein extracts was initiated to identify protein expression level differences between these two closely related bacterial species.

\subsection{Brucella Whole-Cell Protein Extraction}

Preliminary analyses using SDS-PAGE separation (Figure 1) revealed that both B. abortus and $B$. melitensis express very similar sets of proteins with regard to protein pattern and band intensities as well as the occurrence of few differences such as a distinct band around $35 \mathrm{kDa}$ (B. abortus) and below $20 \mathrm{kDa}$ (B. melitensis). The type strains and field strains displayed comparable bands but with varying intensities.

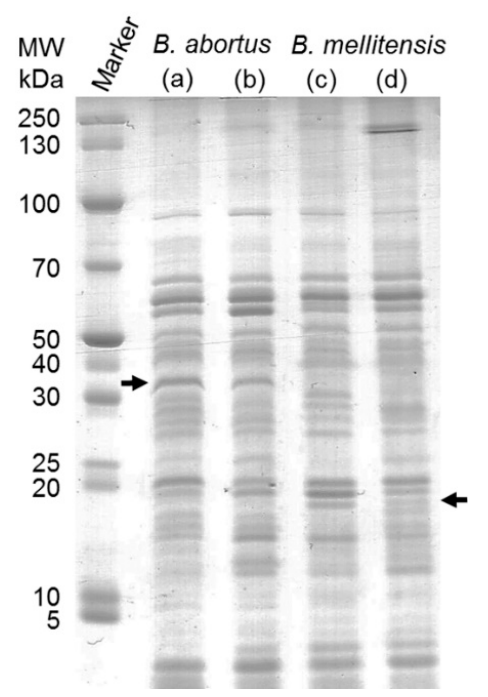

Figure 1. SDS-PAGE separation of whole-cell extract: Lane (a) B. abortus 544, (b) B. abortus T (c) B. melitensis $16 \mathrm{M}$ and (d) B. melitensis C. The strains display comparable bands. Arrows show distinct bands unique for the isolates with $35 \mathrm{kDa}$ in B. abortus and below $20 \mathrm{kDa}$ in B. melitensis. 


\subsection{Databases and Protein Sequences}

Protein identification by matching mass spectra against a database of known sequences is an important tool in proteomics. Despite the availability of a list of differentially expressed proteins and the influences of the physicochemical environment, missing or unknown sequences remain a limiting factor. UniProt listed as many as 458 proteome entries for Brucella, however, 329 entries of proteomic data were redundant and moved to the UniProt Archive (UniParc) database. The remaining nonredundant database represents 10 Brucella species and remains active in the UniProt KB database. UniProt introduced the new term "pan proteome" to describe the entire set of proteins thought to be expressed by a group of highly related organisms, e.g., multiple strains of a species. The pan database entries also included all sequences within a taxonomical group as well as unique sequences not found in the reference proteome [58]. Consequently, 25 proteomes representing 10 species of Brucella were used to create the B. abortus 2308 pan proteome and the B. abortus (strain 2308) proteome remained the reference proteome. An analysis of protein IDs of the pan proteome and five strains of Brucella sp. based on the online software tool InteractiVenn [59] revealed that the complete list of the Brucella reference proteome (except three entries) forms $47 \%$ of the pan proteome (Figure 2). Moreover, the bulk of protein entries in the pan proteome were from B. abortus, B. melitensis, B. suis, B. ovis and B. vulpis, respectively. The Brucella pan proteome contains 7266 protein entries. Their existence was mostly predicted (77\%) or inferred from homology $(21.6 \%)$ whereas evidence at the protein level $(1 \%)$ and transcript level $(0.1 \%)$ was scarce. The manual curation of protein entries was reported for 528 protein entries which correspond to approximately 7.3\% of Brucella-specific protein entries. For MS-based proteome analysis of two species, pan proteome or inclusion of all 10 Brucella proteomes for protein identification might be inconvenient due to the difference in the entry IDs for each species. Therefore, for the sake of effective protein identification, the following two proteomes were combined: (1) $B$. abortus (strain 2308) with a protein count of 3023, distributed on chromosome I (1991) and II (1034, proteome UP000002719, organism ID: 359391. update: 11 February 2017) and (2) B. melitensis biotype 1 (strain 16M/ATCC 23456/NCTC 10094) with a protein count of 3178 distributed on chromosome I (2049) and II (1131, proteome UP000008511, organism ID: 224914. update: 04 February 2017). The latter was redundant and replaced with $B$. melitensis with a protein count of 3123 distributed on chromosome I (1075) and II (2048, proteome UP000290786, organism ID: 29459. update: 01 December 2019, accessed on March 2020). This choice was based on the designation of B. abortus (strain 2308) as reference proteome and the highest number of protein entries among the three available B. melitensis proteomes.

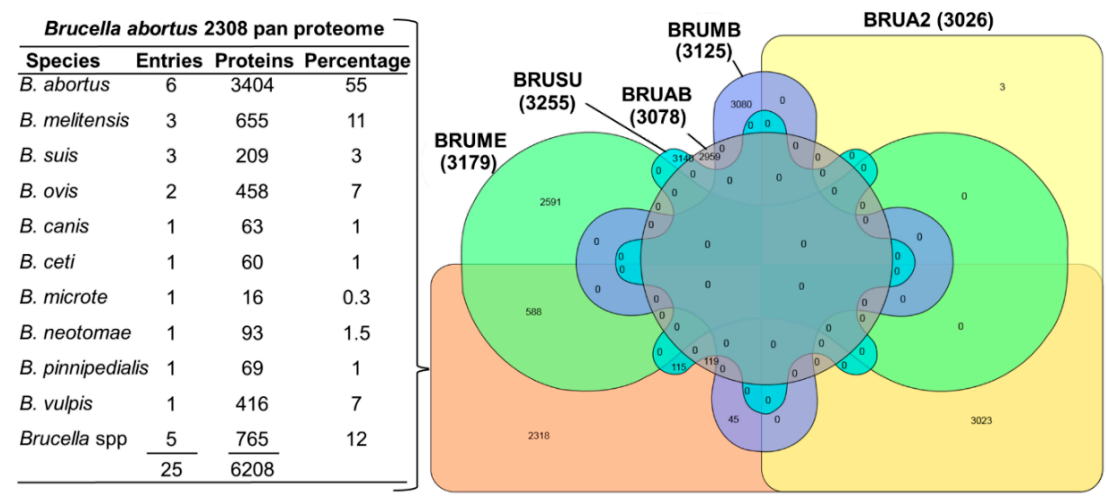

Figure 2. The table lists the Brucella species $(n=10)$ included in the B. abortus 2308 pan proteome. Entries: number of isolates; proteins: number of protein entries and percentage: indicates percentage found in the B. abortus 2308 pan proteome. InteractiVenn diagram of Brucella abortus 2308 pan proteome and the entries of five strains (BRUA2-B. abortus (strain 2308, yellow), BRUAB-B. abortus biovar 1 (strain 9-941, gray), BRUME-B. melitensis biotype 1 (strain 16M/ATCC 23456/NCTC 10094, green), BRUMB-B. melitensis biotype 2 (strain ATCC 23457, purple) and BRUSU-B. suis biovar 1 (strain 1330), blue). 


\subsection{Protein Identification}

A MaxQuant-Andromeda-based search against the combined database of B. abortus (strain 2308) and B. melitensis biotype 1 (strain $16 \mathrm{M}$ ) resulted in the identification of 1202 proteins with at least one unique peptide specific for a protein. A total of 826 proteins were identified, after applying the filter that label-free quantification intensity (LFQ) of a protein was present in at-least four out of six replicates in each sample dataset and after removal of proteins matched toreverse sequences and those proteins identified "by site" (Supplementary Table S1). Among these identified proteins, 478 protein IDs belonged to the $B$. abortus reference proteome and the remaining 348 protein IDs could be allocated to the $B$. melitensis proteome. The distribution of the identified proteins with respect to the chromosomes was 360 on chromosome I (43.6\%) and 118 on chromosome II (14\%) of B. abortus and 161 proteins expressed on chromosome I (19.5\%) and 56 on chromosome II (6.8\%) of B. melitensis. The remaining 131 proteins $(15.7 \%)$ belonged to $B$. melitensis unassembled WGS sequences, which are also part of the $B$. abortus 2308 pan proteome. Later, a database update resulted in the addition of one protein in chromosome I of B. abortus (strain 2308, update 05 December 2016). The proteome UP000008511 was moved to UniParc as it was identified as redundant (update 18 November 2016) and the majority of its protein entries were found to be matching with proteome UP000000419 (update 9 October 2016). As a result, 131 protein entries (belonging to proteome UP000008511: B. melitensis biotype 1) of the 826 identified proteins were found redundant (marked as removed in Supplementary Table S1) or obsolete and deposited at the UniParc database. Consequently, the remaining 695 identified proteins were considered for further analysis.

\subsection{Comparative Proteomics of B. abortus and B. melitensis}

Visualization through unsupervised hierarchical clustering of the proteomic data recapitulated the similarities between strains and species (Figure 3). All six replicates of each isolate clustered together and the species displayed a clear clustering. For comparative proteomics analysis, pairwise comparisons were carried out in six categories as follows,

- $\quad$ Category I: B. melitensis $16 \mathrm{M}$ vs. B. abortus 544 (M vs. A);

- Category II: B. melitensis C vs. B. abortus T (M2 vs. A2);

- Category III: B. melitensis C vs. B. abortus 544 (M2 vs. A);

- Category IV: B. melitensis $16 \mathrm{M}$ vs. B. abortus T (M vs. A2);

- Category V: B. abortus T vs. B. abortus 544 (A2 vs. A);

- Category VI: B. melitensis C vs. B. melitensis 16M (M2 vs. M).

As shown in Figure 3, the volcano plot displays the negative $\log _{10} t$-test $p$-value over the $\log _{2}$ fold-change. Proteins with $p$-values above the dotted line $(p<0.05)$ were considered to be differentially expressed between the two groups. The left side of the plot represents the downregulated proteins and the right side represents the upregulated proteins. Table 2 lists the differentially expressed proteins in each of the above-described categories. The proteins identified as significantly regulated in at least three of the four comparison categories (I-IV) were considered to play a crucial role. As a result, 109 and 104 proteins were identified as up- or downregulated in B. melitensis when compared to B. abortus (Supplementary Table S2). 

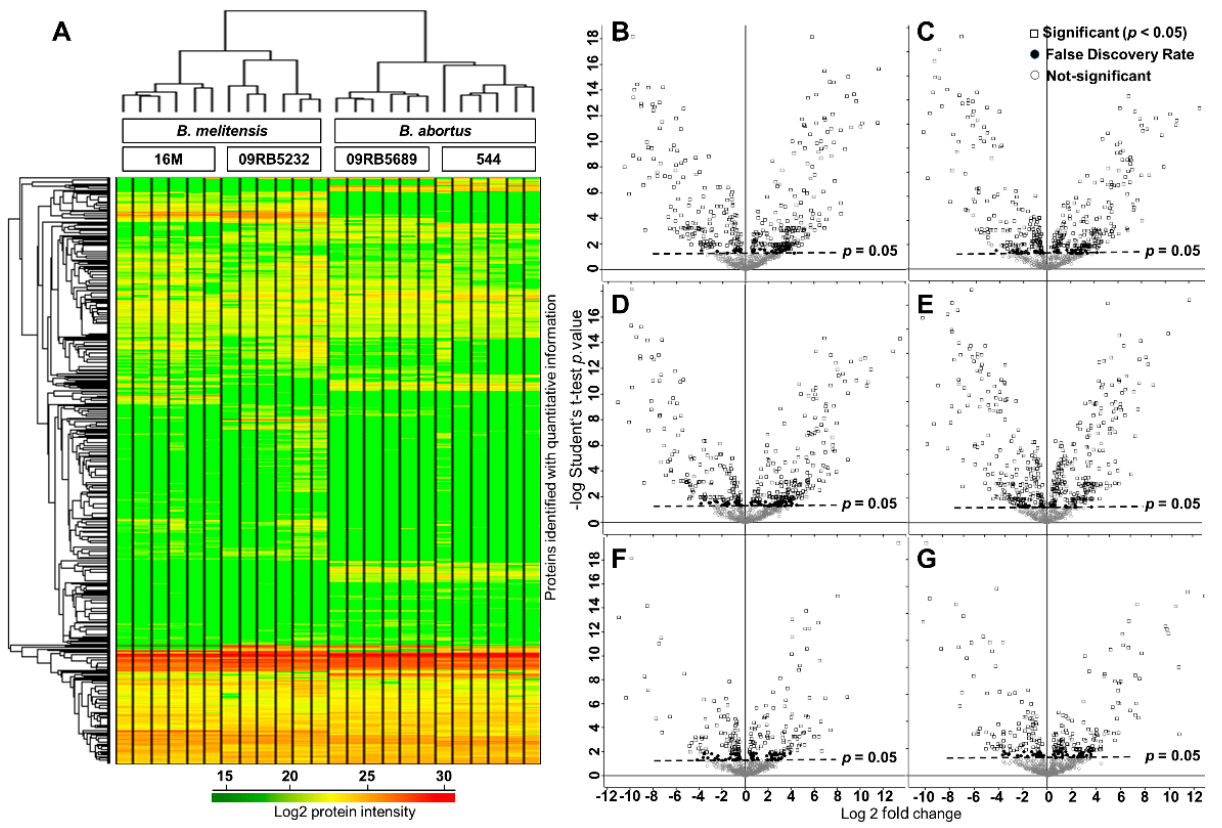

Figure 3. Protein expression profiling using label-free quantitative proteomics analysis. (A) Heat map analysis of 826 proteins among the four dataset groups and with six cultural replicates per group. The $\log _{10}$ value of the MS signal intensity is shown. Hierarchical clustering of proteins of all samples was performed using $z$-score protein intensities for the proteins with $p<0.05$ and based on elucidation distance. Columns indicate the samples, and rows indicate the proteins. Protein expression values were $\log _{2}$-normalized (label-free quantification (LFQ)) intensities of all proteins quantified across the samples, where red and green indicate high and low intensity, respectively. (B-G) Volcano plot for category I-VI, respectively. Ratios plotted for log 2-fold-change ( $x$-axis) against negative $\log p$-value (y-axis) of the Student's $t$-test. Each dot represents a protein.

Table 2. Number of regulated proteins among type and field strains.

\begin{tabular}{ccccccc}
\hline & \multicolumn{7}{c}{ Category } \\
\cline { 2 - 7 } Regulation & I & II & III & IV & V & VI \\
& M vs. A & M2 vs. A2 & M2 vs. A & M vs. A2 & A2 vs. A & M2 vs. M \\
\hline Down- & 173 & 142 & 166 & 223 & 83 & 96 \\
Up- & 216 & 199 & 221 & 248 & 97 & 129 \\
\hline
\end{tabular}

Regulation, down- and up-: downregulated and upregulated, A-B. abortus, A2—B. abortus 544, M-B. melitensis and $\mathrm{M} 2-$ B. melitensis $16 \mathrm{M}$.

\subsection{Geno Ontology and Clusters of Orthologous Groups}

UniProt was used to cluster the proteins in accordance with their Gene Ontologies (GO) for understanding the functional role of the identified proteins. The GO mapping was possible only for those proteins that remained active at the UniProt database until the analysis. GO results presented in Figure 4 include 695 identified proteins among which 66 and 94 were up- or downregulated, respectively, in B. melitensis compared to B. abortus, while Clusters of Orthologous Groups (COGs) are indicated for all 826 identified proteins including 131 redundant proteins. Catalytic activity, binding properties, transporter and antioxidant activity, as well as ribosomal structural constitution, were different between these two species. Macromolecular, membrane and cellular components also varied. The major metabolic and cellular processes appeared to be similar between these species. The prediction of COGs revealed the distribution within four functional groups: cellular processes and signaling $(\mathrm{D}, \mathrm{M}, \mathrm{O}, \mathrm{T}$ and $\mathrm{U})$, information storage and processing $(\mathrm{J}, \mathrm{K}$ and $\mathrm{L})$, metabolism $(\mathrm{C}, \mathrm{E}, \mathrm{F}, \mathrm{G}$, $\mathrm{H}, \mathrm{I}, \mathrm{P}$ and G) and poorly characterized (S). Analysis of about $20 \%$ of the identified proteins identifies any COG. Based on the COG clustering, membrane proteins and proteins involved in biomolecular 
transport and protein synthesis mechanism were found to be enhanced in B. abortus in comparison to B. melitensis.

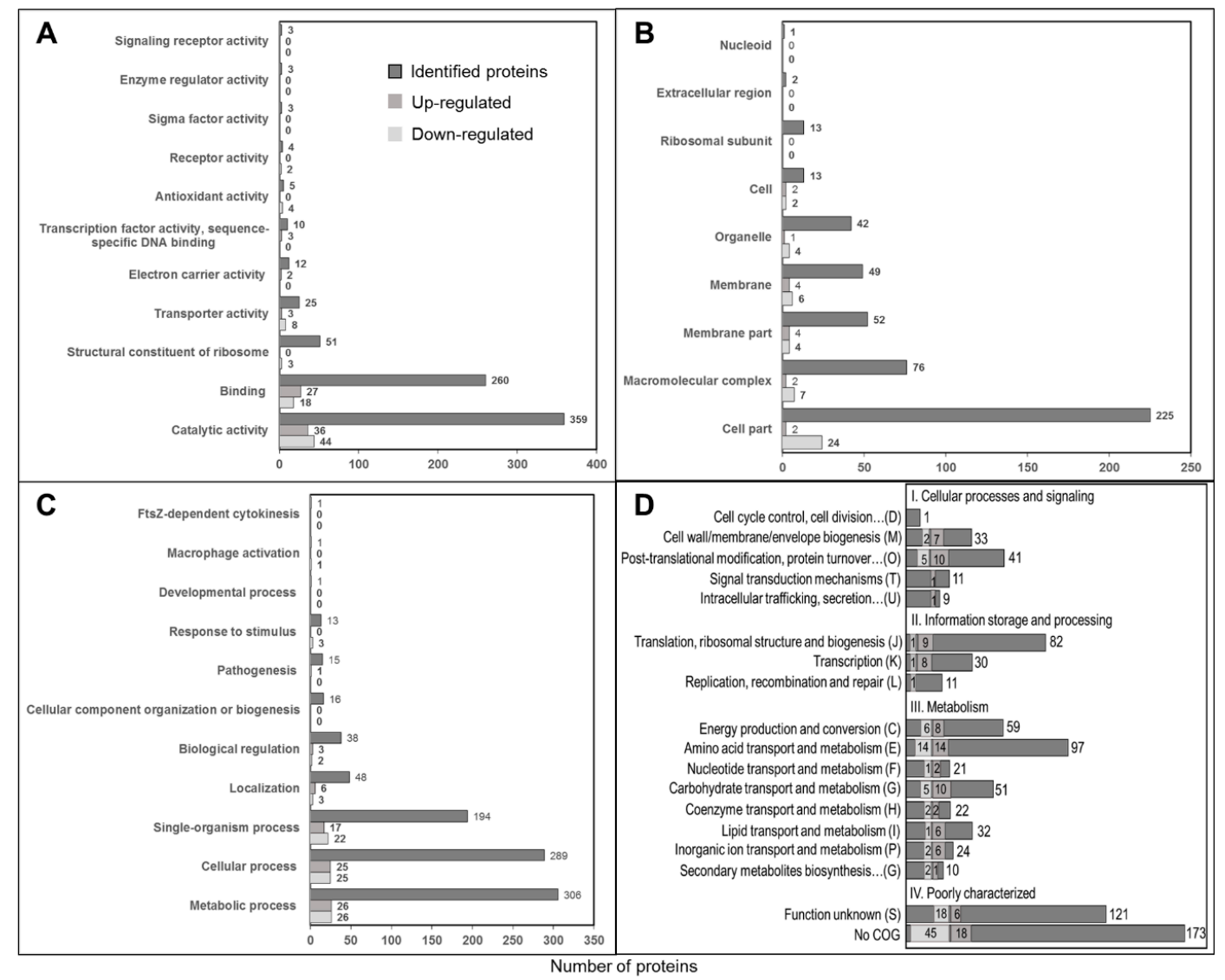

Figure 4. Gene ontology clustering of identified up- and downregulated proteins. (A) Molecular Function (MF), (B) Cellular Component (CC), (C) Biological Process (BP) and (D) Cluster of Orthologous Groups (COGs).

\subsection{Bioinformatics Annotation of Differentially Expressed Proteins}

As shown in Table 3, the DAVID analysis of differentially expressed proteins revealed involvement of several Kyoto Encyclopedia of Genes and Genomes (KEGG) pathways. Notably, histidine metabolism appeared to be different in all compared groups. As shown in Figure 5, among the top 10 pathways, the observed differences in the categories ABC transporters, aminoacyl-tRNA biosynthesis and oxidative phosphorylation merit further investigation to clarify, if these pathways influence biochemical diagnosis or host specificity. The role of ABC transporters in intracellular survival and virulence of Brucella was demonstrated in B. ovis [60]. It was also shown that about $9 \%$ of the coding ability of Brucella is devoted towards ABC transporters, but differences between these two Brucella species were reported [61]. Analysis using DAVID indicated that the proteins downregulated in B. abortus in comparison to B. melitensis occurred within three biological pathways, each with four of the proteins identified: pyruvate metabolism, histidine metabolism, arginine and proline metabolism and lysine degradation, and tryptophan metabolism. In contrast, the upregulated proteins were present in three other pathways: 11 proteins in metabolic pathways, four proteins in carbon metabolism and three proteins in pyrimidine metabolism. 
Table 3. KEGG pathways and the distribution of differentially expressed proteins.

\begin{tabular}{|c|c|c|c|c|c|c|}
\hline \multirow{2}{*}{ KEGG Pathways } & \multicolumn{6}{|c|}{ Category } \\
\hline & I & II & III & IV & $\mathbf{V}$ & VI \\
\hline Metabolic pathways & & $34 \uparrow$ & & & & \\
\hline Carbon metabolism & & & $6 \uparrow$ & & & \\
\hline Glycolysis/gluconeogenesis & & & & $7 \downarrow$ & & \\
\hline Pentose and glucuronate interconversions & & & & & $3 \downarrow$ & \\
\hline Pyruvate metabolism & & & $4 \uparrow$ & & & \\
\hline 2-Oxocarboxylic acid metabolism & $4 \downarrow$ & & & & & \\
\hline Microbial metabolism in diverse environments & & $14 \uparrow$ & $10 \uparrow$ & & & \\
\hline Biosynthesis of amino acids & $11 \downarrow$ & & & $14 \downarrow$ & & \\
\hline Histidine metabolism & $5 \downarrow$ & $5 \downarrow$ & $5 \downarrow$ & $6 \downarrow$ & & \\
\hline Valine, leucine and isoleucine biosynthesis & & & & $4 \downarrow$ & & \\
\hline Purine metabolism & & $7 \uparrow$ & & & & \\
\hline Pyrimidine metabolism & $5 \uparrow$ & $6 \uparrow$ & & $7 \uparrow$ & & \\
\hline Biosynthesis of secondary metabolites & $19 \downarrow$ & & & $25 \downarrow$ & & \\
\hline RNA polymerase & & & & $3 \uparrow$ & & \\
\hline Ribosome & $17 \uparrow$ & $18 \downarrow$ & $14 \downarrow$ & $19 \uparrow$ & & $22 \downarrow$ \\
\hline Bacterial secretion system & & $5 \uparrow$ & $5 \uparrow$ & & $4 \uparrow$ & $5 \uparrow$ \\
\hline $\mathrm{ABC}$ transporters & & & $14 \uparrow$ & & & \\
\hline
\end{tabular}

Number: number of differentially expressed proteins, $\uparrow$ —upregulated, $\downarrow$-downregulated.

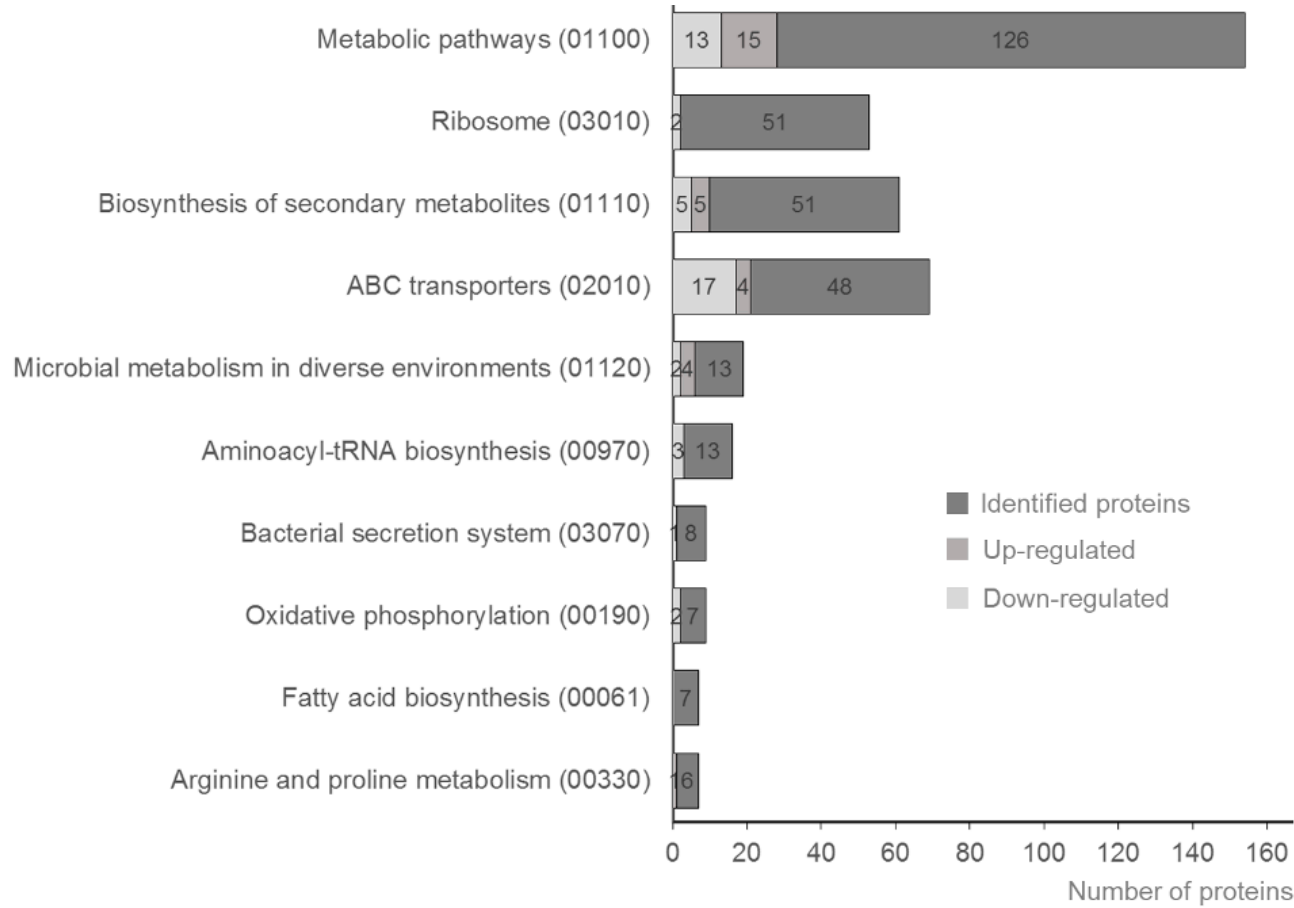

Figure 5. Top 10 KEGG pathways and the distribution of differentially expressed proteins. Number of proteins ( $x$-axis) plotted against KEGG pathways (code) on the $y$-axis to show the number of proteins up- and downregulated when B. abortus compared to B. melitensis. 


\subsection{Predicted Virulence-Associated Proteins}

The prediction of protein pathogenicity was carried out using the freely available online Support Vector Machines (SVM)-based tool VirulentPred [49]. Of the 826 proteins identified, 102 proteins (12\%) were predicted to be potentially virulence-associated (Supplementary Table 3) among which 22 proteins were identified as differentially expressed proteins (16 upregulated and six downregulated in B. abortus comparison to B. melitensis). With the exception of the proteins listed in Table 4, all other differentially expressed proteins predicted as virulence-associated were listed as uncharacterized proteins. The upregulation of potentially virulence-associated proteins and downregulation of ribosomal proteins indicate different degrees of control operations that prepare the bacterial agent for infection [62]. The identified proteins can be explored for further application in diagnostics.

Table 4. Differentially expressed proteins predicted as potentially virulence-associated.

\begin{tabular}{|c|c|c|c|c|}
\hline Acc. & Protein Description & $\operatorname{Reg}$ & Significance & Reference \\
\hline D0B8I3* & Antifreeze protein & $(+)$ & Associated with MucR, a & \multirow{4}{*}{ [63] } \\
\hline Q8YIA9 & Antifreeze protein & $(-)$ & transcriptional regulator & \\
\hline Q2YM39 & Antifreeze protein type I & $(-)$ & linked to Brucella virulence & \\
\hline D0B248* & LipA family protein & $(-)$ & & \\
\hline Q2YIP8 & Lipoprotein Omp10 & $(-)$ & $\begin{array}{l}\text { Reduced virulence in } B \text {. } \\
\text { abortus with gene deletion } \\
\text { and used in diagnostics }\end{array}$ & [64-66] \\
\hline Q2YKV9 & $\begin{array}{l}\text { Superoxide dismutase } \\
{[\mathrm{Cu}-\mathrm{Zn}]}\end{array}$ & $(-)$ & $\begin{array}{l}\text { intracellular survival and } \\
\text { used as antigens for } \\
\text { subunit vaccines }\end{array}$ & {$[19,67]$} \\
\hline Q2YRA8 & $30 \mathrm{~S}$ ribosomal protein S14 & $(-)$ & $\begin{array}{l}\text { role in cellular adhesion } \\
\text { and virulence in Candida } \\
\text { albicans }\end{array}$ & [68] \\
\hline & & & $\begin{array}{c}\text { ribosomal protein L7/L12 } \\
\text { based subunit vaccines }\end{array}$ & {$[69,70]$} \\
\hline
\end{tabular}

Acc. No is the UniProt ID, the protein ID marked with * were moved to UniPrac as they were found to be redundant proteins. Reg-status of protein regulation: (+) denotes upregulation and (-) indicates downregulation of proteins when B. abortus is compared with B. melitensis.

\subsection{Field Strains and Host Adaptability}

Within the same species, the type and field strains also displayed significant variations in the protein abundances. As listed in Supplementary Table S1, the type strain and field strain of B. abortus showed differences in the expression of 180 proteins, among which 97 and 83 proteins were up- and downregulated, respectively, in the field strain when compared to that of the type strain. On the other hand, B. melitensis displayed differences in 224 proteins, among which 129 and 95 were found to be up- or downregulated in the field strain. Among these differentially expressed proteins, as listed in Table 5, 10 proteins including several binding proteins-appeared to be highly abundant among the type strains of both species, while 19 proteins-mostly belonging to the Type IV secretion system (T4SS) - were highly abundant among the field strains of B. abortus and B. melitensis. T4SS has been associated with increased host adaptability and described as an essential pathogenicity factor in several pathogens including Brucella spp., Helicobacter pylori, Legionella pneumophila and Bartonella spp [71,72]. T4SS influences the intracellular survival in the host $[73,74]$. Nine proteins identified as upregulated in the $B$. abortus field strain were found to be downregulated in the field strain of B. melitensis. On the other hand, seven proteins identified as upregulated in the B. melitensis field strain were found to be downregulated in the B. abortus field strain. These proteins are worth further analysis as they might play a role in the known host-species specificity and might be useful for designing species-specific diagnostic tools. 
Table 5. Differentially expressed proteins among the field isolates in comparison to that of the respective type strains.

\begin{tabular}{|c|c|}
\hline UniProt ID & Protein \\
\hline \multicolumn{2}{|r|}{ Downregulated in Field Isolates } \\
\hline Q8YBH7 & Bacterial extracellular solute-binding protein family 1 \\
\hline Q8YIX9 & Glyceraldehyde-3-phosphate dehydrogenase \\
\hline Q2YMI0 & Phosphatidylserine decarboxylase proenzyme \\
\hline Q2YLU2 & Peptidylprolyl isomerase \\
\hline Q2YLF8 & Leu/Ile/Val-binding protein homolog 1 \\
\hline Q2YLG0 & Leu/Ile/Val-binding protein homolog 2 \\
\hline Q2YJA9 & Leu/Ile/Val-binding protein homolog 5 \\
\hline Q2YQQ6 & Glutelin:Lipoprotein YaeC family:NLPA lipoprotein \\
\hline Q2YRP7 & Ribosome-recycling factor \\
\hline Q2YR20 & Uncharacterized protein \\
\hline \multicolumn{2}{|r|}{ Upregulated in Field Isolates } \\
\hline Q2YJ78 & Type IV secretion system protein virB8 \\
\hline Q2YJ79 & Type IV secretion system protein virB9 \\
\hline Q2YJ81 & Type IV secretion system protein virB10 \\
\hline Q2YJ83 & Type IV secretion system-outer membrane lipoprotein \\
\hline Q2YJ77 & Type IV secretion system putative lipoprotein virB7 \\
\hline Q8YB25 & Alpha-methylacyl-CoA racemase \\
\hline Q2YIG7 & NADH:flavin oxidoreductase/NADH oxidase \\
\hline Q2YKS6 & Aminotransferase class IV \\
\hline Q8YCZ2 & $\mathrm{N}$-acetylglucosamine-6-phosphate deacetylase \\
\hline Q8YI04 & ATP-dependent DNA ligase \\
\hline Q2YK32 & Catalase \\
\hline Q2YLX9 & Lipoprotein putative \\
\hline Q2YN45 & Probable cytosol aminopeptidase \\
\hline Q2YRJ0 & ATP/GTP-binding site motif A (P-loop) \\
\hline Q2YRN7 & Uncharacterized protein \\
\hline Q8YBU9 & Putative uroporphyrin-iii c-methyltransferase \\
\hline Q2YKY2 & Uncharacterized protein \\
\hline Q2YL40 & Uncharacterized protein \\
\hline Q2YLM7 & Uncharacterized protein \\
\hline \multicolumn{2}{|c|}{ Downregulated in B. abortus and Upregulated in B. melitensis } \\
\hline Q2YME1 & Threonylcarbamoyl-AMP synthase \\
\hline Q2YNW9 & Dihydroxy-acid dehydratase \\
\hline Q8YHA5 & Glutaryl-CoA dehydrogenase \\
\hline Q2YP66 & Zinc-containing alcohol dehydrogenase \\
\hline Q2YQE3 & Periplasmic binding protein \\
\hline Q2YMW1 & Uncharacterized protein \\
\hline Q2YPK6 & Uncharacterized protein \\
\hline \multicolumn{2}{|c|}{ Upregulated in B. abortus and Downregulated in B. melitensis } \\
\hline Q2YQV7 & $50 S$ ribosomal protein L20 \\
\hline Q2YR56 & 50 S ribosomal protein $\mathrm{L} 28$ \\
\hline Q2YRY0 & ABC-type glycine betaine transport system \\
\hline Q8YBF5 & $\begin{array}{c}\text { Maltose-binding periplasmic protein (Sugar ABC } \\
\text { transporter) }\end{array}$ \\
\hline Q8YCD1 & Cystine-binding periplasmic protein \\
\hline Q8YGE8 & Cationic amino acid $\mathrm{ABC}$ transporter \\
\hline Q2YKN7 & Uncharacterized protein \\
\hline Q2YKN9 & Uncharacterized protein \\
\hline Q2YQM2 & Uncharacterized protein \\
\hline
\end{tabular}

\section{Conclusions}

In conclusion, our quantitative proteomic analysis of reference and field-isolated strains of $B$. abortus and B. melitensis not surprisingly confirms the existence of proteome level differences between 
the strains. Besides differences in metabolic pathways, B. abortus and B. melitensis displayed differences in $A B C$ transporters, which were shown to play a role in intracellular survival and virulence of Brucella. Field isolates displayed enhanced abundance in several binding proteins and Type IV secretion systems (T4SS), these have been associated with host adaptability and essential pathogenic factors. B. abortus field strain displayed a high abundance of 10 proteins and seven proteins were of high abundance in B. melitensis. These proteins might be playing a role in host specificity. With the exception of seven proteins, all other proteins $(n=15)$ identified as potentially virulence-associated were uncharacterized proteins. Problems arise from the existence of multiple redundant reference proteomes for different Brucella species. The benefits of the recently introduced pan proteome concept based on protein entries of 10 known Brucella species also remain limited, as long as the majority of protein entries at the UniProt database remain unreviewed/curated. Establishing a species-specific proteome would be useful for understanding the host specificity and infection of Brucella species. We suggest that in addition to improvements in the reference database, further in-depth proteomic analyses are performed on these strains cocultured with their respective host cell lines. This might lead to an understanding of the mechanism lying behind the described host specificity and pathogenicity.

Supplementary Materials: The following are available online at http://www.mdpi.com/2218-273X/10/6/836/s1, Table S1: List of identified proteins; Table S2: List of differentially expressed proteins; Table S3: Virulence-associated protein prediction result.

Author Contributions: Conceptualization, J.M., G.W. and H.N.; methodology, J.M., G.W., M.E. and C.W.; data analysis, J.M.; writing—original draft preparation, J.M.; writing—reviewing and editing, U.R., L.D.S. and H.N.; All authors have read and agreed to the published version of the manuscript.

Funding: This work is supported by an internal fund from the FLI. The author Murat Eravci was supported by the Deutsche Forschungsgemeinschaft (DFG, SFB 958).

Acknowledgments: The authors would like to thank Michael Kühl for excellent technical support. For mass spectrometry (Christoph Weise and Murat Eravci), we would like to acknowledge the assistance of the Core Facility BioSupraMol supported by the Deutsche Forschungsgemeinschaft (DFG). We would like to thank the Academy of Scientific Research and Technology (ASRT) Egypt for partial financial support. This work is part of the BrucMedNet project (ID: 698) funded by the ARIMNet2. The assistance in grammatical corrections by Marc Howard Rich, SRM University AP, Andhra Pradesh is greatly appreciated.

Conflicts of Interest: The authors declare no conflict of interest.

\section{References}

1. Moreno, E.; Stackebrandt, E.; Dorsch, M.; Wolters, J.; Busch, M.; Mayer, H. Brucella abortus 16S rRNA and lipid A reveal a phylogenetic relationship with members of the alpha-2 subdivision of the class Proteobacteria. J. Bacteriol. 1990, 172, 3569-3576. [CrossRef] [PubMed]

2. Cardoso, P.G.; Macedo, G.C.; Azevedo, V.; Oliveira, S.C. Brucella spp noncanonical LPS: Structure, biosynthesis, and interaction with host immune system. Microb. Cell Fact. 2006, 5, 13. [CrossRef] [PubMed]

3. Christopher, S.; Umapathy, B.L.; Ravikumar, K.L. Brucellosis: Review on the recent trends in pathogenicity and laboratory diagnosis. J. Lab. Physicians 2010, 2, 55-60. [CrossRef] [PubMed]

4. Whatmore, A.M. Current understanding of the genetic diversity of Brucella, an expanding genus of zoonotic pathogens. Infect. Genet. Evol. 2009, 9, 1168-1184. [CrossRef] [PubMed]

5. Verger, J.M.; Grimont, F.; Grimont, P.A.D.; Grayon, M. Brucella, a Monospecific Genus as Shown by Deoxyribonucleic-Acid Hybridization. Int. J. Syst. Bacteriol. 1985, 35, 292-295. [CrossRef]

6. Brenner, D.; Staley, J.; Krieg, N. Classification of Procaryotic Organisms and the Concept of Bacterial Speciation. In Bergey's Manual ${ }^{\circledR}$ of Systematic Bacteriology; Brenner, D., Krieg, N., Staley, J., Garrity, G., Eds.; Springer US: New York, NY, USA, 2005; pp. 27-32.

7. Chain, P.S.; Comerci, D.J.; Tolmasky, M.E.; Larimer, F.W.; Malfatti, S.A.; Vergez, L.M.; Aguero, F.; Land, M.L.; Ugalde, R.A.; Garcia, E. Whole-genome analyses of speciation events in pathogenic Brucellae. Infect. Immun. 2005, 73, 8353-8361. [CrossRef]

8. Halling, S.M.; Peterson-Burch, B.D.; Bricker, B.J.; Zuerner, R.L.; Qing, Z.; Li, L.L.; Kapur, V.; Alt, D.P.; Olsen, S.C. Completion of the genome sequence of Brucella abortus and comparison to the highly similar genomes of Brucella melitensis and Brucella suis. J. Bacteriol. 2005, 187, 2715-2726. [CrossRef] 
9. Wang, Y.; Ke, Y.; Wang, Z.; Yuan, X.; Qiu, Y.; Zhen, Q.; Xu, J.; Li, T.; Wang, D.; Huang, L.; et al. Genome sequences of three live attenuated vaccine strains of Brucella species and implications for pathogenesis and differential diagnosis. J. Bacteriol. 2012, 194, 6012-6013. [CrossRef]

10. Singh, D.K.; Kumar, A.; Tiwari, A.K.; Sankarasubramanian, J.; Vishnu, U.S.; Sridhar, J.; Gunasekaran, P.; Rajendhran, J. Draft Genome Sequence of Brucella abortus Virulent Strain 544. Genome Announc. 2015, 3. [CrossRef]

11. DelVecchio, V.G.; Kapatral, V.; Redkar, R.J.; Patra, G.; Mujer, C.; Los, T.; Ivanova, N.; Anderson, I.; Bhattacharyya, A.; Lykidis, A.; et al. The genome sequence of the facultative intracellular pathogen Brucella melitensis. Proc. Natl. Acad. Sci. USA 2002, 99, 443-448. [CrossRef]

12. Rajashekara, G.; Glasner, J.D.; Glover, D.A.; Splitter, G.A. Comparative whole-genome hybridization reveals genomic islands in Brucella species. J. Bacteriol. 2004, 186, 5040-5051. [CrossRef] [PubMed]

13. Cloeckaert, A.; Verger, J.M.; Grayon, M.; Paquet, J.Y.; Garin-Bastuji, B.; Foster, G.; Godfroid, J. Classification of Brucella spp. isolated from marine mammals by DNA polymorphism at the omp2 locus. Microbes. Infect. Inst. Pasteur 2001, 3, 729-738. [CrossRef]

14. Cloeckaert, A.; Vizcaino, N.; Paquet, J.Y.; Bowden, R.A.; Elzer, P.H. Major outer membrane proteins of Brucella spp.: Past, present and future. Vet. Microbiol. 2002, 90, 229-247. [CrossRef]

15. Adone, R.; Muscillo, M.; La Rosa, G.; Francia, M.; Tarantino, M. Antigenic, immunologic and genetic characterization of rough strains B. abortus RB51, B. melitensis B115 and B. melitensis B18. PLoS ONE 2011, 6, e24073. [CrossRef] [PubMed]

16. Yang, Y.; Wang, L.; Yin, J.; Wang, X.; Cheng, S.; Lang, X.; Wang, X.; Qu, H.; Sun, C.; Wang, J.; et al. Immunoproteomic analysis of Brucella melitensis and identification of a new immunogenic candidate protein for the development of brucellosis subunit vaccine. Mol. Immunol. 2011, 49, 175-184. [CrossRef] [PubMed]

17. Al Dahouk, S.; Nöckler, K.; Scholz, H.C.; Tomaso, H.; Bogumil, R.; Neubauer, H. Immunoproteomic characterization of Brucella abortus 1119-3 preparations used for the serodiagnosis of Brucella infections. J. Immunol. Methods 2006, 309, 34-47. [CrossRef] [PubMed]

18. Tabynov, K.; Ryskeldinova, S.; Sansyzbay, A. An influenza viral vector Brucella abortus vaccine induces good cross-protection against Brucella melitensis infection in pregnant heifers. Vaccine 2015, 33, 3619-3623. [CrossRef]

19. Dorneles, E.M.; Sriranganathan, N.; Lage, A.P. Recent advances in Brucella abortus vaccines. Vet. Res. 2015, 46, 76. [CrossRef]

20. Al Dahouk, S.; Tomaso, H.; Nockler, K.; Neubauer, H.; Frangoulidis, D. Laboratory-based diagnosis of brucellosis-A review of the literature. Part II: Serological tests for brucellosis. Clin. Lab. 2003, 49, 577-589.

21. Al Dahouk, S.; Scholz, H.C.; Tomaso, H.; Bahn, P.; Gollner, C.; Karges, W.; Appel, B.; Hensel, A.; Neubauer, H.; Nockler, K. Differential phenotyping of Brucella species using a newly developed semi-automated metabolic system. BMC Microbiol. 2010, 10, 269. [CrossRef]

22. Alton, G.G.; Forsyth, J.R.L. Brucella. In Medical Microbiology, 4th ed.; Baron, S., Ed.; University of Texas Medical Branch at Galveston: Galveston, TX, USA, 1996.

23. Wareth, G.; Eravci, M.; Weise, C.; Roesler, U.; Melzer, F.; Sprague, L.D.; Neubauer, H.; Murugaiyan, J. Comprehensive identification of immunodominant proteins of Brucella abortus and Brucella melitensis using antibodies in the sera from naturally infected hosts. Int. J. Mol. Sci. 2016, 17, 659. [CrossRef]

24. Wareth, G.; Melzer, F.; Weise, C.; Neubauer, H.; Roesler, U.; Murugaiyan, J. Proteomics-based identification of immunodominant proteins of Brucellae using sera from infected hosts points towards enhanced pathogen survival during the infection. Biochem. Biophys. Res. Commun. 2015, 456, 202-206. [CrossRef] [PubMed]

25. Connolly, J.P.; Comerci, D.; Alefantis, T.G.; Walz, A.; Quan, M.; Chafin, R.; Grewal, P.; Mujer, C.V.; Ugalde, R.A.; DelVecchio, V.G. Proteomic analysis of Brucella abortus cell envelope and identification of immunogenic candidate proteins for vaccine development. Proteomics 2006, 6, 3767-3780. [CrossRef] [PubMed]

26. DelVecchio, V.G.; Wagner, M.A.; Eschenbrenner, M.; Horn, T.A.; Kraycer, J.A.; Estock, F.; Elzer, P.; Mujer, C.V. Brucella proteomes-A review. Vet. Microbiol. 2002, 90, 593-603. [CrossRef]

27. Eschenbrenner, M.; Horn, T.A.; Wagner, M.A.; Mujer, C.V.; Miller-Scandle, T.L.; DelVecchio, V.G. Comparative proteome analysis of laboratory grown Brucella abortus 2308 and Brucella melitensis 16M. J. Proteome Res. 2006, 5, 1731-1740. [CrossRef] 
28. Eschenbrenner, M.; Wagner, M.A.; Horn, T.A.; Kraycer, J.A.; Mujer, C.V.; Hagius, S.; Elzer, P.; DelVecchio, V.G. Comparative proteome analysis of Brucella melitensis vaccine strain Rev 1 and a virulent strain, 16M. J. Bacteriol. 2002, 184, 4962-4970. [CrossRef]

29. Lamontagne, J.; Beland, M.; Forest, A.; Cote-Martin, A.; Nassif, N.; Tomaki, F.; Moriyon, I.; Moreno, E.; Paramithiotis, E. Proteomics-based confirmation of protein expression and correction of annotation errors in the Brucella abortus genome. BMC Genom. 2010, 11, 300. [CrossRef]

30. Mujer, C.V.; Wagner, M.A.; Eschenbrenner, M.; Horn, T.; Kraycer, J.A.; Redkar, R.; Hagius, S.; Elzer, P.; Delvecchio, V.G. Global analysis of Brucella melitensis proteomes. Ann. N. Y. Acad. Sci. 2002, 969, 97-101. [CrossRef]

31. Paredes-Cervantes, V.; Flores-Mejia, R.; Moreno-Lafont, M.C.; Lanz-Mendoza, H.; Tello-Lopez, A.T.; Castillo-Vera, J.; Pando-Robles, V.; Hurtado-Sil, G.; Gonzalez-Gonzalez, E.; Rodriguez-Cortes, O.; et al. Comparative proteome analysis of Brucella abortus 2308 and its virB type IV secretion system mutant reveals new T4SS-related candidate proteins. J. Proteom. 2011, 74, 2959-2971. [CrossRef]

32. Wagner, M.A.; Eschenbrenner, M.; Horn, T.A.; Kraycer, J.A.; Mujer, C.V.; Hagius, S.; Elzer, P.; DelVecchio, V.G. Global analysis of the Brucella melitensis proteome: Identification of proteins expressed in laboratory-grown culture. Proteomics 2002, 2, 1047-1060. [CrossRef]

33. Zai, X.; Yang, Q.; Yin, Y.; Li, R.; Qian, M.; Zhao, T.; Li, Y.; Zhang, J.; Fu, L.; Xu, J.; et al. Relative Quantitative Proteomic Analysis of Brucella abortus Reveals Metabolic Adaptation to Multiple Environmental Stresses. Front. Microbiol. 2017, 8, 2347. [CrossRef] [PubMed]

34. Zai, X.; Yang, Q.; Liu, K.; Li, R.; Qian, M.; Zhao, T.; Li, Y.; Yin, Y.; Dong, D.; Fu, L.; et al. A comprehensive proteogenomic study of the human Brucella vaccine strain 104 M. BMC Genom. 2017, 18, 402. [CrossRef] [PubMed]

35. Laemmli, U.K. Cleavage of structural proteins during the assembly of the head of bacteriophage T4. Nature 1970, 227, 680-685. [CrossRef]

36. Candiano, G.; Bruschi, M.; Musante, L.; Santucci, L.; Ghiggeri, G.M.; Carnemolla, B.; Orecchia, P.; Zardi, L.; Righetti, P.G. Blue silver: A very sensitive colloidal Coomassie G-250 staining for proteome analysis. Electrophoresis 2004, 25, 1327-1333. [CrossRef]

37. Murugaiyan, J.; Eravci, M.; Weise, C.; Roesler, U. Label-free quantitative proteomic analysis of harmless and pathogenic strains ofinfectious microalgae, Prototheca spp. Int. J. Mol. Sci. 2016, 18, 59. [CrossRef]

38. Rappsilber, J.; Ishihama, Y.; Mann, M. Stop and go extraction tips for matrix-assisted laser desorption/ionization, nanoelectrospray, and LC/MS sample pretreatment in proteomics. Anal. Chem. 2003, 75, 663-670. [CrossRef] [PubMed]

39. Cox, J.; Neuhauser, N.; Michalski, A.; Scheltema, R.A.; Olsen, J.V.; Mann, M. Andromeda: A peptide search engine integrated into the MaxQuant environment. J. Proteome Res. 2011, 10, 1794-1805. [CrossRef] [PubMed]

40. Cox, J.; Matic, I.; Hilger, M.; Nagaraj, N.; Selbach, M.; Olsen, J.V.; Mann, M. A practical guide to the MaxQuant computational platform for SILAC-based quantitative proteomics. Nat. Protoc. 2009, 4, 698-705. [CrossRef] [PubMed]

41. Luber, C.A.; Cox, J.; Lauterbach, H.; Fancke, B.; Selbach, M.; Tschopp, J.; Akira, S.; Wiegand, M.; Hochrein, H.; O'Keeffe, M.; et al. Quantitative proteomics reveals subset-specific viral recognition in dendritic cells. Immunity 2010, 32, 279-289. [CrossRef]

42. Cox, J.; Hein, M.Y.; Luber, C.A.; Paron, I.; Nagaraj, N.; Mann, M. Accurate proteome-wide label-free quantification by delayed normalization and maximal peptide ratio extraction, termed MaxLFQ. Mol. Cell. Proteom. 2014, 13, 2513-2526. [CrossRef]

43. Benjamini, Y.; Hochberg, Y. Controlling the false discovery rate-A practical and powerful approach to multiple testing. J. R. Stat. Soc. B Met. 1995, 57, 289-300. [CrossRef]

44. Vizcaino, J.A.; Csordas, A.; Del-Toro, N.; Dianes, J.A.; Griss, J.; Lavidas, I.; Mayer, G.; Perez-Riverol, Y.; Reisinger, F.; Ternent, T.; et al. 2016 update of the PRIDE database and its related tools. Nucleic Acids Res. 2016, 44, 11033. [CrossRef] [PubMed]

45. Vizcaino, J.A.; Deutsch, E.W.; Wang, R.; Csordas, A.; Reisinger, F.; Rios, D.; Dianes, J.A.; Sun, Z.; Farrah, T.; Bandeira, N.; et al. ProteomeXchange provides globally coordinated proteomics data submission and dissemination. Nat. Biotechnol. 2014, 32, 223-226. [CrossRef] [PubMed] 
46. Huerta-Cepas, J.; Szklarczyk, D.; Forslund, K.; Cook, H.; Heller, D.; Walter, M.C.; Rattei, T.; Mende, D.R.; Sunagawa, S.; Kuhn, M.; et al. eggNOG 4.5: A hierarchical orthology framework with improved functional annotations for eukaryotic, prokaryotic and viral sequences. Nucleic Acids Res. 2016, 44, D286-D293. [CrossRef]

47. Huang, D.W.; Sherman, B.T.; Lempicki, R.A. Systematic and integrative analysis of large gene lists using DAVID bioinformatics resources. Nat. Protoc. 2009, 4, 44-57. [CrossRef]

48. Huang, D.W.; Sherman, B.T.; Lempicki, R.A. Bioinformatics enrichment tools: Paths toward the comprehensive functional analysis of large gene lists. Nucleic Acids Res. 2009, 37, 1-13. [CrossRef]

49. Garg, A.; Gupta, D. VirulentPred: A SVM based prediction method for virulent proteins in bacterial pathogens. BMC Bioinform. 2008, 9, 62. [CrossRef]

50. Perez-Riverol, Y.; Csordas, A.; Bai, J.; Bernal-Llinares, M.; Hewapathirana, S.; Kundu, D.J.; Inuganti, A.; Griss, J.; Mayer, G.; Eisenacher, M.; et al. The PRIDE database and related tools and resources in 2019: Improving support for quantification data. Nucleic Acids Res. 2019, 47, D442-D450. [CrossRef]

51. Meyer, M.E.; Morgan, W.J. Metabolic characterization of Brucella strains that show conflicting identity by biochemical and serological methods. Bull. World Health Organ. 1962, 26, 823-827.

52. He, Y. Analyses of Brucella pathogenesis, host immunity, and vaccine targets using systems biology and bioinformatics. Front. Cell. Infect. Microbiol. 2012, 2, 2. [CrossRef]

53. Teixeira-Gomes, A.P.; Cloeckaert, A.; Bezard, G.; Dubray, G.; Zygmunt, M.S. Mapping and identification of Brucella melitensis proteins by two-dimensional electrophoresis and microsequencing. Electrophoresis 1997, 18, 156-162. [CrossRef] [PubMed]

54. Crasta, O.R.; Folkerts, O.; Fei, Z.; Mane, S.P.; Evans, C.; Martino-Catt, S.; Bricker, B.; Yu, G.; Du, L.; Sobral, B.W. Genome sequence of Brucella abortus vaccine strain S19 compared to virulent strains yields candidate virulence genes. PLoS ONE 2008, 3, e2193. [CrossRef] [PubMed]

55. Lamontagne, J.; Forest, A.; Marazzo, E.; Denis, F.; Butler, H.; Michaud, J.F.; Boucher, L.; Pedro, I.; Villeneuve, A.; Sitnikov, D.; et al. Intracellular adaptation of Brucella abortus. J. Proteome Res. 2009, 8, 1594-1609. [CrossRef] [PubMed]

56. Tsoktouridis, G.; Merz, C.A.; Manning, S.P.; Giovagnoli-Kurtz, R.; Williams, L.E.; Mujer, C.V.; Hagius, S.; Elzer, P.; Redkar, R.J.; Patra, G.; et al. Molecular characterization of Brucella abortus chromosome II recombination. J. Bacteriol. 2003, 185, 6130-6136. [CrossRef]

57. Teixeira-Gomes, A.P.; Cloeckaert, A.; Zygmunt, M.S. Characterization of heat, oxidative, and acid stress responses in Brucella melitensis. Infect. Immun. 2000, 68, 2954-2961. [CrossRef]

58. UniProt. UniProt: The universal protein knowledgebase. Nucleic Acids Res. 2017, 45, D158-D169. [CrossRef]

59. Heberle, H.; Meirelles, G.V.; da Silva, F.R.; Telles, G.P.; Minghim, R. InteractiVenn: A web-based tool for the analysis of sets through Venn diagrams. BMC Bioinform. 2015, 16. [CrossRef]

60. Silva, T.M.A.; Mol, J.P.S.; Winter, M.G.; Atluri, V.; Xavier, M.N.; Pires, S.F.; Paixao, T.A.; Andrade, H.M.; Santos, R.L.; Tsolis, R.M. The Predicted ABC Transporter AbcEDCBA Is Required for Type IV Secretion System Expression and Lysosomal Evasion by Brucella ovis. PLoS ONE 2014, 9. [CrossRef]

61. Jenner, D.C.; Dassa, E.; Whatmore, A.M.; Atkins, H.S. ATP-Binding Cassette Systems of Brucella. Comp. Funct. Genom. 2009, 354649. [CrossRef]

62. Smircich, P.; Eastman, G.; Bispo, S.; Duhagon, M.A.; Guerra-Slompo, E.P.; Garat, B.; Goldenberg, S.; Munroe, D.J.; Dallagiovanna, B.; Holetz, F.; et al. Ribosome profiling reveals translation control as a key mechanism generating differential gene expression in Trypanosoma cruzi. BMC Genom. 2015, 16. [CrossRef]

63. Caswell, C.C.; Elhassanny, A.E.; Planchin, E.E.; Roux, C.M.; Weeks-Gorospe, J.N.; Ficht, T.A.; Dunman, P.M.; Roop, R.M., II. Diverse genetic regulon of the virulence-associated transcriptional regulator MucR in Brucella abortus 2308. Infect. Immun. 2013, 81, 1040-1051. [CrossRef] [PubMed]

64. Tibor, A.; Wansard, V.; Bielartz, V.; Delrue, R.M.; Danese, I.; Michel, P.; Walravens, K.; Godfroid, J.; Letesson, J.J. Effect of omp10 or omp19 deletion on Brucella abortus outer membrane properties and virulence in mice. Infect. Immun. 2002, 70, 5540-5546. [CrossRef] [PubMed]

65. Goolab, S.; Roth, R.L.; van Heerden, H.; Crampton, M.C. Analyzing the molecular mechanism of lipoprotein localization in Brucella. Front. Microbiol. 2015, 6. [CrossRef] [PubMed]

66. Simborio, H.L.T.; Lee, J.J.; Reyes, A.W.B.; Hop, H.T.; Arayan, L.T.; Min, W.; Lee, H.J.; Yoo, H.S.; Kim, S. Evaluation of the combined use of the recombinant Brucella abortus Omp10, Omp19 and Omp28 proteins for the clinical diagnosis of bovine brucellosis. Microb. Pathog. 2015, 83-84, 41-46. [CrossRef] 
67. Gee, J.M.; Valderas, M.W.; Kovach, M.E.; Grippe, V.K.; Robertson, G.T.; Ng, W.L.; Richardson, J.M.; Winkler, M.E.; Roop, R.M. The Brucella abortus $\mathrm{Cu}, \mathrm{Zn}$ superoxide dismutase is required for optimal resistance to oxidative killing by murine macrophages an wild-type virulence in experimentally infected mice. Infect. Immun. 2005, 73, 2873-2880. [CrossRef]

68. Kim, S.W.; Joo, Y.J.; Kim, J. Asc1p, a ribosomal protein, plays a pivotal role in cellular adhesion and virulence in Candida albicans. J. Microbiol. 2010, 48, 842-848. [CrossRef]

69. Du, Z.Q.; Li, X.; Wang, J.Y. Immunogenicity analysis of a novel subunit vaccine candidate molecule-recombinant L7/L12 ribosomal protein of Brucella suis. Appl. Biochem. Biotechnol. 2016, 179, 1445-1455. [CrossRef]

70. Jain, S.; Kumar, S.; Dohre, S.; Afley, P.; Sengupta, N.; Alam, S.I. Identification of a protective protein from stationary-phase exoproteome of Brucella abortus. Pathog. Dis. 2014, 70, 75-83. [CrossRef]

71. Atluri, V.L.; Xavier, M.N.; de Jong, M.F.; den Hartigh, A.B.; Tsolis, R.M. Interactions of the human pathogenic Brucella Species with their hosts. Annu. Rev. Microbiol. 2011, 65, 523-541. [CrossRef]

72. Saenz, H.L.; Engel, P.; Stoeckli, M.C.; Lanz, C.; Raddatz, G.; Vayssier-Taussat, M.; Birtles, R.; Schuster, S.C.; Dehio, C. Genomic analysis of Bartonella identifies type IV secretion systems as host adaptability factors. Nat. Genet. 2007, 39, 1469-1476. [CrossRef]

73. Boschiroli, M.L.; Ouahrani-Bettache, S.; Foulongne, V.; Michaux-Charachon, S.; Bourg, G.; Allardet-Servent, A.; Cazevieille, C.; Lavigne, J.P.; Liautard, J.P.; Ramuz, M.; et al. Type IV secretion and Brucella virulence. Vet. Microbiol. 2002, 90, 341-348. [CrossRef]

74. Wattam, A.R.; Williams, K.P.; Snyder, E.E.; Almeida, N.F.; Shukla, M.; Dickerman, A.W.; Crasta, O.R.; Kenyon, R.; Lu, J.; Shallom, J.M.; et al. Analysis of ten Brucella genomes reveals evidence for horizontal gene transfer despite a preferred intracellular lifestyle. J. Bacteriol. 2009, 191, 3569-3579. [CrossRef] [PubMed]

(C) 2020 by the authors. Licensee MDPI, Basel, Switzerland. This article is an open access article distributed under the terms and conditions of the Creative Commons Attribution (CC BY) license (http://creativecommons.org/licenses/by/4.0/). 